\title{
9 \\ A Criminal Legal Biopolitics: The Case of Voluntary Assisted Dying
}

\author{
David J Carter ${ }^{1}$
}

\section{Introduction}

Voluntary assisted dying ('VAD') marks a distinct shift in the governance of death in Australia. One aspect of this shift is a movement away from a governance of death dominated in juridical terms by the criminal law and its practices. Instead, deaths brought about according this new regime are framed as belonging to the domain of medical and health law and its practices. This characterisation of VAD as involving a shift from criminal law to medical and health law, however, fails to fully capture the vital and ongoing role that the criminal law plays in the establishment and operation of VAD itself. For this reason, this chapter approaches the Voluntary Assisted Dying Act 2017 (Vic) ('the Act') as an instrument of the criminal law. It attends to the legal material of the legislation enabling VAD - the very 'black letter' of VAD law - and argues that it remains fundamentally criminal in nature, despite its reception as a regime that belongs to the

1 Senior Lecturer in Law, Faculty of Law, University of Technology Sydney. National Health and Medical Research Council ('NHMRC') Early Career Fellow (Grant ID: 1156520). The contents are solely the responsibility of the individual author and do not reflect the views of NHMRC. Visiting Fellow, Brocher Foundation, Switzerland. This research was supported by the Law | Health | Justice Research Centre at the University of Technology Sydney and the Brocher Foundation where much of the writing was completed as a Visiting Fellow. 
domain of medical and health law and its attendant normative and other practices. This analysis of the legal 'machinery' of VAD is not undertaken for the sake of legal classificatory ends alone. Rather, acknowledging that $\mathrm{VAD}$ and the new biopolitical configuration it brings about remains deeply reliant upon the criminal law renders visible the 'biopolitics of criminal law'; that is, how criminal law achieves a rationing of life by its organisation of a differential distribution of death within a population to be governed. Building on Ben Golder's articulation of the criminal sanction as a tactic of biopolitics, I describe how criminal law achieves its biopolitical work in the domain of VAD.

\section{Voluntary assisted dying: From criminal law to healthcare}

Voluntary assisted dying ('VAD') marks a shift in the governance of death in Australia. Assisted dying of the sort now legal in Victoria ${ }^{2}$ - and soon elsewhere ${ }^{3}$ - has been neither legal nor an openly acknowledged part of the management of death. For this reason, the legalisation and bureaucratisation of this form of dying represents an immediate change to the landscape of death and its governance, with impacts not only on the availability of VAD itself, but also upon other practices from palliative care and other medical specialties, end-of-life planning, religious organisations' provision of state-funded healthcare services, and health services planning. In these ways, VAD represents a profound reshaping of the governance of death, including in areas beyond the immediate bounds of this new way of seeking assistance to die that VAD ushers in.

Among the various changes that the advent of VAD brings about is a shift in the specifically juridical and regulatory aspects of the governance of death. Primarily, this has been characterised as a shift in the locus of the legal regulation of death from the criminal law and its institutions to that of healthcare law and practice. ${ }^{4}$ This is achieved, in legal terms at least, by way of the Voluntary Assisted Dying Act 2017 (Vic) ('the Act'). The Act aims to provide 'Victorians with the genuine choices they need,

\footnotetext{
2 See Voluntary Assisted Dying Act 2017 (Vic).

3 Voluntary Assisted Dying Act 2019 (WA).

4 Compare Kenneth Veitch's analysis in the same assisted dying context in the United Kingdom ('the movement from medicalisation to legalisation'): Kenneth Veitch, 'Medical Law and the Power of Life and Death' (2006) 2(2) International Journal of Law in Context 137.
} 
in line with their preferences, to have a good end of life and death. ${ }^{5}$ To achieve this, the Act makes two 'moves', juridically speaking. The first is to reform the multiple layers of criminal liability that had prevented both patients and their families, carers and health practitioners from legally engaging in, or cooperating with, assisted dying. The second is to establish a range of practical matters for the provision and governance of VAD by the state through the medical and healthcare professions and associated bureaucracy. With the advent of VAD, then, the longstanding practical and symbolic dominance of the criminal law, its knowledges and institutions, its normative content and practices is diminished - or some might say 'overcome' - replaced by a state-managed process that places medical knowledge and healthcare systems at its centre.

This progression from the centrality of criminal law to a greater role of medical and healthcare authorities and knowledges is no accidental outcome of the Act. Rather, this transition from criminal law to the medical disciplines is the purpose of these reforms. Shepherded by the Minister for Health, administered by the government department responsible for healthcare and human services provision, and entirely reliant upon health and medical expertise and systems, VAD is designed to bring about an almost total transition from governance by the criminal law to the health and social care domain in both rhetorical, practical and juridical terms.

VAD's reliance upon the complex apparatus of medicine and healthcare knowledges, institutions and practices means that not only is there a shift from a governance dominated by the criminal law to that of healthcare, it also places us in biopolitical 'territory'. The hallmarks of the biopolitical, as articulated by Foucault and those who follow in that tradition, are central to the character of VAD as constructed in Victoria: the Act establishes, authorises and mobilises an array of medical and state authorities who are authorised to interpret a set of 'truth discourses' ${ }^{3}$ about the vital character of living human beings while it establishes the legal, regulatory, practical and supportive biopower interventions that will be applied to

5 Victoria, Parliamentary Debates, Legislative Assembly, 21 September 2017, 2949 (Jill Hennessy, Minister for Health).

6 Ben Golder, 'The Distribution of Death: Notes towards a Bio-Political Theory of Criminal Law' in Matthew Stone, Illan rua Wall and Costas Douzinas (eds), New Critical Legal Thinking: Law and the Political (Taylor \& Francis, 2012) 91, 110. 
the emergent biosocial collectivity of 'the dying'7. This characterisation of VAD as a largely biopolitical exercise of power is further reinforced by the 'periodization' of VAD as emerging in contrast to - and as an 'overcoming' of - a now outmoded, troubled and 'unsettled's governance of death dominated by the criminal law and its institutions.

Naming VAD an exercise of biopolitical power is not controversial. ${ }^{9}$ Rather, many others have named various forms of assisted dying regimes as biopolitical in nature. ${ }^{10}$ Want I want to pursue in this chapter, however, is an examination of how the juridical and regulatory aspects of VAD - its legal 'machinery' - forges and partakes in this exercise of biopower. Such a focus is unusual in terms of biopolitical analyses of assisted dying regimes, and even rare in biopolitical analyses mounted outside of assisted dying contexts. This is because biopolitical analyses understand techniques other than law as (more) central to the formulation and operation of biopower. Not only this, the dominant view of this particular tradition reads law and legal techniques as progressively less central to the operation of power in modernity. This is an established reading of Foucault's articulation of power that interprets him as describing a shift from a time of law's ascendency to one of law's subordination to newer technologies of power - namely discipline and biopower - and thus a receding of the importance of legal technologies as elements in the exercise of power today. ${ }^{11}$

7 Courtney Hempton and Catherine Mills, 'Constitution of "the Dying": Voluntary Assisted Dying Law Reform in the Australian State of Victoria' (Conference Paper, Australasian Association of Bioethics and Health Law, 2 July 2018); Courtney Hempton and Catherine Mills, 'Constitution of "the Already Dying”: The Emergence of Voluntary Assisted Dying in Victoria' (2021) 18(2) Journal of Bioethical Inquiry 265 doi.org/10.1007/s11673-021-10107-1.

8 Thomas Faunce, 'Justins v The Queen: Assisted Suicide, Juries and the Discretion to Prosecute' (2011) 18 Journal of Law and Medicine 706, 110.

9 There is, however, some controversy or tension regarding the implications of naming assisted dying in this way - or in alternate ways, like 'thanatopolitics'. See Braidotti for a concise overview of the differing conceptions of biopolitics and their varied implications for naming VAD in this way: Rosi Braidotti, 'The Politics of "Life Itself" and New Ways of Dying' in Diana Coole and Samantha Frost (eds), New Materialisms: Ontology, Agency, and Politics (Duke University Press, 2010) 204-6.

10 To name but a few works that engage with the varied relationship between euthanasia/assisted dying and a biopolitical frame, see Gürhan Özpolat, 'Between Foucault and Agamben: An Overview of the Problem of Euthanasia in the Context of Biopolitics' (2017) 7(2) Beytulhikme An International Journal of Philosophy 15; Todd F McDorman, 'Controlling Death: Bio-Power and the Right-toDie Controversy' (2005) 2(3) Communication and Critical/Cultural Studies 257; Anna E Kubiak, 'The Discourse of Biopower against Disturbances of the Boundary between Life and Death' (2011) 15(Special) Annales Universitatis Apulensis Series Historica 481; Anna E Kubiak, 'Assisted Dying in the Context of Biopower' (2015) 21(1) Anthropological Notebooks 13; Brett Neilson, 'Anti-Ageing Cultures, Biopolitics and Globalisation' (2006) 12(2) Cultural Studies Review 149.

11 For an overview and critique of this view, see Ben Golder and Peter Fitzpatrick, Foucault's Law (Routledge-Cavendish, 2009). 
With my focus on law, then, I am pursuing an unusual and perhaps even controversial position that sees not only law, but the criminal law in particular, as central to the establishment and exercise of biopower. This follows in the footsteps of Ben Golder in particular, who has used the Homosexual Advance Defence of the criminal law to illuminate the "tactical" bio-political role of law"12 in aid of his formulation of a biopolitical theory of criminal law. In that analysis, Golder has been able to demonstrate that the criminal law itself has an important biopolitical role, in contradistinction from the body of writing that sees law - and the criminal law perhaps most particularly - as playing a much diminished role in the operation of biopolitical regimes.

So too am I developing my own intellectual project that attempts to render visible the fundamental and abiding relations between healthcare, medicine, and public health and the criminal law. This is a relation that I have worked to demonstrate and critique - often in the face of a body of scholarship and practice that disavows healthcare and public health's relation to the criminal law, attempting to define its very nature and practice as specifically separate and independent from that of the criminal law. ${ }^{13}$

VAD provides another moment to exercise and extend both of these analyses. Following Golder's lead, I want to 'illuminate the "tactical" bio-political role of law ${ }^{14}$ through a criminal legal reading of the Act. In so doing, I ask whether the Act really represents an overcoming of the criminal law and its role in the governance of death. In response, I argue that, in fact, it does not; rather than an overcoming of governance by the criminal law, VAD is achieved by use of the criminal law. Indeed, the raw 'legal machinery' of VAD is, as I demonstrate in the following pages, fundamentally criminal in nature and so its biopolitical effects are - in large part - produced by the criminal law, and in particular the ordering of criminal sanctioning found within the Act.

12 Golder (n 6) 110.

13 See, for example, David J Carter, 'The Use of Coercive Public Health and Human Biosecurity Law in Australia: An Empirical Analysis' (2020) 43 University of New South Wales Law Journal 117; David J Carter, 'Transmission of HIV and the Criminal Law: Examining the Impact of Pre-Exposure Prophylaxis and Treatment-as-Prevention' (2020) 43(3) Melbourne University Law Review 937; David J Carter, 'HIV Transmission, Public Health Detention and the Recalcitrant Subject of Discipline: Kuoth, Lam v R and the Co-Constitution of Public Health and Criminal Law' (2016) 25(2) Griffith Law Review 172.

14 Golder (n 6) 110. 
To begin to unpack how the ordering of criminal sanctioning found within the Act operates as a biopolitical tactic, I first outline - briefly - the nature of biopower and the biopolitical in the work of Foucault and those who write in his wake. I focus especially upon the difficult relationship that characterises criminal law and biopolitics in that literature. I then engage with Ben Golder's articulation of the criminal sanction as a tactic of biopolitics, moving, finally, to describe how criminal law achieves its biopolitical work in the domain of VAD by way of its structuring of the field, its production of this new form of 'voluntary assisted' dying, and the use of VAD to expand and entrench criminal law's reach with greatly expanded, rather than contracted, criminal offences.

\section{Biopolitics, the role of criminal law and the distribution of death}

Adding to his conception of 'disciplinary' power, Foucault introduced the concept of biopower/biopolitics in the mid-1970s. Emerging in 1976 in the first volume of Foucault's study of sexuality, known in English as The History of Sexuality, ${ }^{15}$ this new paradigm did not focus upon the drive towards adherence to the norm by individuals, as is the signal feature of disciplinary power. Instead, it focused upon a political rationality and associated technologies that are focused upon the governance of a population using technologies of power that address the management of, and control over, the life of the population. At the most elemental level, biopower is the bringing to bear upon life, the body and the population a series of rational attempts to foster and manage life. Marked by methods that focus on mortality and morbidity, birth and indicators of relative health or of behavioural risk of a population, biopower is concerned with the "vital" character of living human beingss"16 enacted through the imposition of an anatamo-politics of the individual body, and bio-politics of the collective/population. ${ }^{17}$

VAD regimes like that in Victoria place us in 'biopolitical territory'. Most obviously, VAD regimes are an exercise of governance focused, perhaps in the most raw or direct way, upon life through the management of

15 Michel Foucault, The History of Sexuality. Volume 1: The Will to Knowledge, tr Robert Hurley (Penguin, 1998) ('History of Sexuality').

16 Paul Rabinow and Nikolas Rose, 'Biopower Today' (2006) 1(2) BioSocieties 195, 197.

17 Foucault, History of Sexuality (n 15) 139. 
vitality and maximisation of (a certain kind of) life: two elements that are hallmarks of so much biopolitically inflected activity. ${ }^{18}$ Paul Rabinow and Nikolas Rose propose what is now a classic threefold 'test' for identifying biopower, which is helpful in clarifying how, in more specific terms, VAD is an exercise of biopower. For them, fundamental signals as to its operation are the presence of 'truth discourses' 19 and a competent authority to speak the truth regarding the vital character of living human beings. This is joined by a collection of interventions that flow from this discursive apparatus, which are exercised in the name of life; which are addressed to populations; which may or may not be territorialised upon the nation, society or pre-given communities; and, important for our purposes, which may also be specified in terms of emergent biosocial collectivities. ${ }^{20}$ Finally, they note that the working of biopower includes modes of subjectivisation where individuals are enjoined to engage in various practices of the self, directed by the competent authorities and discursive regimes. ${ }^{21}$ The VAD regime performs these very moves. It constructs, authorises and mobilises an array of medical and state authorities who together are the only authorities empowered to decide who qualifies and who may access VAD. ${ }^{22}$ The permit system established by the Act requires such interpretation, with medical practitioners called upon to confirm that a person has six or 12 months to live in order to proceed through the permit issuing process. ${ }^{23}$ It develops and implements legal, regulatory, practical and supportive interventions like the institution of 'VAD Navigators' ${ }^{24}$ and the complex logistical system of medication provision, storage, management and re-collection, all applied in the name of life and health to the emergent biosocial collectivity of 'the already dying'. ${ }^{25}$ Finally, it enjoins people to engage in practices of the self that might be helpfully described as 'living and dying well', where practices of care are expressed in and through the exercise of a new freedom to choose death.

18 Braidotti (n 9) 201.

19 Rabinow and Rose (n 16) 197.

20 Ibid.

21 Ibid.

22 See for example the Voluntary Assisted Dying Act (n 2) s 10 (minimum qualifications for those acting as co-ordinating medical practitioners), and see ss 26-7.

23 Ibid ss 16, 18(4).

24 Kristian Silva, 'Voluntary Euthanasia Patients Caught in Red-Tape Bottleneck', ABC News (online, 18 July 2019) <https:/www.abc.net.au/news/2019-07-18/voluntary-euthanasia-patientscaught-in-red-tape-bottleneck/11320626>.

25 Hempton and Mills, 'Constitution of "the Dying”' (n 7). 
Despite VAD being clearly in 'biopolitical terrain', a challenge arises in relation to a biopolitical analysis of VAD due to the regime's intense and uniform focus upon 'death' rather than 'life'. A focus on life makes more immediate sense for a biopolitical regime or analysis, for, with a focus upon death, power could be said to have lost its object of its governance. Death could be seen, in this sense, as 'beyond ... power, ${ }^{26}$ and potentially 'outside the power relationship ... Death is beyond the reach of power, and power has a grip on it only in general, overall, or statistical terms' ${ }^{27}$ For this reason, VAD sits somewhat awkwardly with relation to the theorisation of biopolitics most present in the literature, where life and the governance of living beings has been the touchstone of biopolitical analysis and theory.

Death and the power over death have a place within a biopolitical regime or analysis. Foucault's own theorisation of these questions admits as much, where he explained that biopolitics stood for the 'break between what must live and what must die'. And other thinkers have noted the connection between the two, within a biopolitical paradigm, where:

new practices of 'life' mobilize not only generative forces but also new and subtler degrees of extinction ... [ushering in a] type of vitality, unconcerned by clear-cut distinctions between living and dying. ${ }^{28}$

As Ben Golder puts it, biopower operates not only with a concern for 'making provision for the protection of life', but in this vein 'precisely as a mechanism for the [differential] distribution of death'. ${ }^{29}$ To understand the central place of death within biopower - a form of power concerned primarily with life and its governance - we must return to Foucault's own formulation of biopower. ${ }^{30}$

Having established the biopolitical tenor of the operation of power in modernity, Foucault remained troubled by the state's continued use of death after the emergence of this and other new(er) technologies of power.

26 Özpolat (n 10) 21.

27 Michel Foucault, 'Society Must Be Defended': Lectures at the Collège de France, 1975-1976

(Picador, Reprint ed, 2003) 247-248 ('Society Must Be Defended'), cited in Özpolat (n 10) 21.

28 Braidotti (n 9) 203.

29 Golder (n 6) 94.

30 Rosi Braidotti, 'Biomacht und nekro-Politik. Uberlegungen zu einer Ethik der Nachhaltigkeit [Bio-Power and Necro-Politics. Reflections on an Ethic of Sustainability]' (2007) 13(2) Springerin: Hefte fur Gegenwartskunst 18. For a clear explication see Braidotti's work here, including her synthesis of the differing interpretations following Foucault present at the time of writing. 
For example, after describing the emergence of discipline and biopower and demonstrating their firm establishment and dominance as forms of power in modernity, Foucault asked how it was that power continued to 'exercise its highest prerogatives by putting people to death, when its main role was to ensure, sustain, and multiply life, to put this life in order?'31

There are a range of ways by which responses to this question have been forged, such that death and dying are seen to take their place as a part of the exercise of biopower in modernity as 'a power to foster life or disallow it to the point of death'. ${ }^{32}$ Much of this debate centres on whether the concept of biopolitics can 'accommodate' death, and if so in what ways. In this chapter I draw on Ben Golder's response, ${ }^{33}$ whereby he is able to demonstrate that biopolitics and biopower accommodate death - in fact, that they necessarily must. This is not the only approach to death and biopolitics. Anna Kubiak, for example, has written carefully about this question in the specific domain of assisted dying and biopolitics, concluding that the conceptual apparatus of biopolitics proves insufficient to account for the 'subjugation of death'34 that assisted dying presents. She prefers 'thanatopolitics' 35 - a politics of death - that is made up of 'strategies of biopower in contemporary industrialised societies' to the use of biopolitics in the domain of assisted dying/euthanasia. I feel an affinity for the notion that assisted dying presents us with a 'special' case. However, I think that Golder's alternate/re-emphasis on death as a part of biopolitics allows for the continued use of biopolitics but without the need for renaming it or developing another theoretical apparatus. For these reasons, I provide a recapitulation of Golder's approach in the following paragraphs.

In Golder's engagement with this question of death and biopolitics, he draws upon the celebrated discussion of the 'repressive hypothesis' by Foucault in order to answer the question posed by him; a question posed in pages immediately after he deals with the repressive hypothesis. ${ }^{36}$ As is well known, Foucault's reflection on silence and speech in relation to the

\footnotetext{
31 Foucault, History of Sexuality (n 15).

32 Ibid 138.

33 Golder (n 6).

34 Kubiak, 'Assisted Dying in the Context of Biopower' (n 10) 24.

35 Ibid 24 ('As Achille Mbembe ... reveals, "the notion of biopower is insuffcient to account for contemporary forms of subjugation of life" ... and, I would add, subjugation of death. For this, I refer to the concept of "thanatopolitics"').

36 Foucault, History of Sexuality (n 15) 138.
} 
repressive hypothesis describes a significant explosion of speech about sex by way of counteracting the accepted understanding of the Victorian relationship to sex thought to have been marked primarily by widespread repression expressed as silence about the topic. On the contrary, Foucault argued, the rise of repression that is generally believed to begin in the seventeenth century leads not to silence but to 'a veritable discursive explosion ${ }^{37}$ where a 'a discursive ferment that gathered momentum ${ }^{38}$ by way of a 'steady proliferation of discourses concerned with sex'. ${ }^{39}$ This abundance of speech about sex, however, was accompanied by silences. These silences were not an absence or censorship of 'sex talk', but were instead integral parts of an overarching discursive structuring and practice of the discourse itself:

Silence itself-the things one declines to say, or is forbidden to name, the discretion that is required between different speakersis less the absolute limit of discourse, the other side from which it is separated by a strict boundary, than an element that functions alongside the things said, with them and in relation to them within over-all strategies ... . There is not one but many silences, and they are an integral part of the strategies that underlie and permeate discourses. ${ }^{40}$

Indeed, for Foucault, censorship regarding sex is not exercised most effectively by way of enforced silence, but by way of continual encouragement or demand to speak about sex - to the disciplinary professions - in order to better regulate it.

Golder draws a parallelism between the interplay between silence/speech in relation to Foucault's treatment of the repressive hypothesis and the interplay between death/life in the operation of biopower in modernity. In the same way that speech about sex and silence about sex are intimately bound together, so too are the relations of death/life similarly structured. Golder is here extending the same structure of silence/speech into the domain of death/life claiming that 'just as in the midst of speech there is a necessary silence, so too in the midst of life there are necessary deaths'. ${ }^{41}$

\footnotetext{
37 Ibid 17.

38 Ibid 18.

39 Ibid.

40 Ibid 27.

41 Golder, (n 6) 100.
} 
But what are these 'necessary' deaths of biopolitics? What are the sites within which (bio)power exercises its role of ensuring, sustaining and multiplying life by way of killing? The examples Golder provides are those that Foucault himself uses: war and the death penalty. ${ }^{42}$ Both reveal for Foucault the disciplinary imperative to 'correct (and in default of this to delete) the aberrant individual' ${ }^{43}$ by way of killing. For Foucault and Golder this is how the power concerned with enhancing the vital character of human beings comes to kill, '[o]ne had the right to kill those who represented a kind of biological danger to others. ${ }^{44}$

VAD regimes are, I claim, another site where biopower comes to kill. Naturally enough, the characterisation of VAD-like regimes as biopolitical has been made by a number of scholars. However, no-one has yet engaged the specifically legal nature of these regimes in specifically biopolitical terms. That is, how the formal juridical instantiation of VAD law - that is, its 'black letter', doctrinal and associated institutional apparatus operates in a 'bio-political register'. ${ }^{45}$

This challenge of how law - particularly in its 'black letter' form - can be integrated into a biopolitical analysis requires work to resolve. Perhaps the most significant difficulty of integrating law into a biopolitical analysis is the theoretical terrain itself. As analytics of power, Foucauldian approaches are understood to be interested in tracing the development of new technologies of power like discipline and biopower. Because of their 'recentness' in Foucault's historical rendering of them, the 'newness' of these technologies of power are contrasted with 'older' forms of sovereign/ deductive power that operate through what Foucault usually referred to as 'juridical power' or, as we would term it, 'formal law' and its institutions (the court, judge etc). This chronology as embedded within Foucault's body of work structures a contrast between premodern forms of power that utilise techniques of juridical power, like criminal law, with technologies of power like biopower that do not find their primary expression through law but through various extra-legal strategies.

This chronological narrative structure provides a sense of historical progression between these forms of power, with newer forms of power being understood to overtake and replace older technologies of power and

42 Foucault, History of Sexuality (n 15) 137.

43 Golder (n 6) 101.

44 Foucault, History of Sexuality (n 15) 138; and see Golder (n 6) 101.

45 Golder (n 6) 95. 
their attendant strategies. Moreover, these newer forms of power we see below were described variously by Foucault as 'counter-law', as 'alien to that of the law', ${ }^{46}$ further building the sense that law was to be replaced by these newer technologies of power. Given this structuring of power in Foucault's body of work, interpreters of Foucault have generally received his description of power according to a template of law's expulsion from the general economy of power in modernity. This 'expulsion thesis' in the post-Foucault literature, is based on the reading of Foucault that sees him regard law - perhaps especially in its criminal guise - as:

essentially negative (and violent) in its mode of operation; historically tied to monarchical sovereignty; and, finally, with the transition to modernity, overtaken by more productive and effective technologies of power which invest it and instrumentally subordinate it to their operations. ${ }^{47}$

As to biopower specifically, there Foucault writes '[o]ne might say that the ancient right to take life or let live was replaced by a power to foster life or disallow it to the point of death'. ${ }^{48}$

This quasi-'Whiggish' view of a progressive supplanting of technologies of power that rely on law over time is not the only challenge to an analysis that attends to the specifically legal nature of biopolitical regimes like VAD. So too is the attempt to isolate 'law' for analysis a significant challenge - rather than a version of law as enmeshed in extrajuridical discourse of discipline and the sciences. For when writers do engage law on its own, a 'good Foucauldian' (!) would plainly reject any engagement with such 'formal law' (ie juridical power) if divorced from the numerous extrajuridical technologies of power. This would be a too-partial and false separating out of the workings of power. ${ }^{49}$ While this strategy is orthodoxy within Foucauldian scholarship, and I believe a broadly correct view of law, it has also resulted in an inattention to the specifics of law and thus a partial analysis of law and legal materials, as well as misreadings of its operation at times. For this reason, attentiveness to law in some detail even if artificially isolated from its enmeshing in other forms of rule and technologies of power - is a useful prolegomena to broader analyses of the operation of power in modernity.

46 Michel Foucault cited in Golder and Fitzpatrick (n 11) 23.

47 Golder and Fitzpatrick (n 11) 15.

48 Foucault, History of Sexuality (n 15) 138.

49 This is a point that Golder grapples with well: see Golder (n 6) 93. 


\section{The criminal sanctions of voluntary assisted dying}

In this section I will claim that the criminal sanction remains at the heart of VAD. To do so, I will briefly review the construction of the Act to demonstrate the centrality of the criminal sanction to its operation. I will claim that the criminal sanction shapes the landscape of the Act and of $\mathrm{VAD}$, and is the fundamental legal mechanism through which the Act comes to produce voluntary assisted dying. Finally, this leads to a claim made in the following section that the criminal legal/juridical sanction is the mechanism by which the criminal law performs its distributive biopolitical role. There I conclude by noting how strange this continued and even expanded position of criminal law is within this domain - given the construction of VAD as explicitly a transition away from - perhaps also a 'rejection' of - a governance of this form of death as dominated by the criminal law.

The Act was passed by the Victorian parliament in November 2017. An implementation period followed its enactment, and the regime came into force in mid-2019. ${ }^{50}$ The Act permits an adult with decision-making capacity who is resident in Victoria to seek assistance from a medical practitioner to die. It permits medical and other health practitioners, as well as other persons, to participate in the request to access VAD and its implementation. It permits these two processes where they conform to a strictly defined process established in large part by the Act itself.

In the following paragraphs I establish how the Act is an instrument of criminal sanction: in its use of criminal sanctions to give structure to the Act itself, through its establishment of detailed processes to administer VAD that are given authority and 'grip' in their identity by the criminal law and, finally, in the Act's affirmation not only of existing homicide sanctions, but its enactment of a number of new serious criminal sanctions. These three movements come together to produce VAD as death that takes place within the space of a limited and complex mixture of status and process that the criminal law constructs and from which the criminal law offers its protection.

50 For more detail, see the Introduction to this volume. 
First as to the structuring of the Act itself. The structure to which I refer is of the 'legal ordering' of the Act. By this I do not mean the Act/Part/ Section structure of the legislative text as such. Rather, I mean how it is that 'legal machinery' is arranged and mobilised by the Act, ordered so as to give meaning and effect to its provisions. This, I claim, is achieved in legal terms by way of the criminal sanctioning regime established in the Act. ${ }^{51}$ The criminal sanctioning regime upon which the Act is based is found in a series of sections in Parts 7 and 8 of the Act. ${ }^{52}$ These are structured as both imposition(s) of liability and confirmation of where liability will not be found. The Act, for example, defines participation in particular processes as that which will provide protection or 'safe-harbour' from criminal liability: for persons who assist or facilitate requests for access to VAD, for health practitioners who act in accordance with the Act or who do not apply resuscitation following administration of the voluntary assisted dying substance and for those who do not attempt to use justified force to prevent suicide in these circumstances. ${ }^{53}$ This is, however, not a decriminalisation move. The Act does not decriminalise as such, but instead engages in a strategy of making explicit - by way of detailed description of VAD process and relevant status questions - the boundaries of criminal illegality. At the level of doctrinal and legislative detail, it simply (re)describes and thus establishes the circumstances where homicide or other criminal offences will be committed or not, leaving the criminal offence(s) untouched.

51 By 'criminal sanction', I am here following Ben Golder - again - by embracing the 'semantic and juridical ambiguity of the sanction as that which both allows and disallows'. However, I am not fully convinced that this is necessarily the best way of describing what the criminal law is doing in the instance of VAD. The VAD regime is one that operates in and through criminal law - and specifically by criminal law's strategic withdrawal from the scene of VAD, that is from specific instances of death delivered by the healthcare system. While the language of sanction can name both allowing and disallowing, I wonder if it fails to highlight how in criminal law's choosing to sanction/allow VAD it also cedes territory or jurisdiction over death to discipline's jurisdiction. By seeing criminal law's work being at the boundary of discipline's jurisdiction, we see criminal law allowing healthcare as a disciplinary power to make and maintain a claim of 'jurisdiction' over the supervision and correction of normality (by deciding who may access VAD), unchallenged in its authority by criminal law. On the other hand, the language of sanction can also be supplemented by a sense of criminal law's supervision or oversight of this space of disciplinary power carved out from criminal law's jurisdiction, which may also achieve the same end.

52 Voluntary Assisted Dying Act (n 2) ss 75-82 and ss 83-91 respectively.

53 Ibid ss 79-82. 
Not only does the Act establish by (re)description when an offence will have been committed, it also establishes an entire set of new criminal offences - many of which are punishable by a gaol term of life imprisonment. ${ }^{54}$ These offences include offences not to comply with a practitioner administration permit, ${ }^{55}$ or to knowingly administer to another person a voluntary assisted dying substance that has been dispensed according to a self-administration permit. ${ }^{56}$ This represents a major widening (in the sense of 'net widening') of the terrain now covered by criminal offences. So too does it represent an increase in the raw number of homicide offences in the jurisdiction, including those of the most serious nature. This widening of the jurisdiction of criminal law and the concomitant increase in the number of serious offences is, it should be recalled, all performed in aid of establishing VAD; a process that was to see the falling away of the criminal law's dominance of the governance of death has resulted instead in a net expansion of the criminal law in the field.

But what of the complex and lengthy set of processes that the Act creates? Like those relating to the issuing of permits or management of the VAD substance? Certainly, the bulk of the legislative text of the Act is taken up with describing medical and administrative processes for the request, assessment, granting of permits and governance of the VAD regime. However, despite appearances, these process elements are best understood as a form of 'superstructure' erected on and reliant upon a foundation of criminal sanction. They are given legal meaning and effect only in and through their establishment upon a criminal foundation.

How does this work in practice? In short, each of the processes is tethered to a criminal sanction that provides legal effect to the provisions. For example, where VAD processes are followed, those requesting and those executing VAD processes are sanctioned by the criminal law - they will not be subject to criminal liability for having done so. ${ }^{57}$ Alternately, where VAD processes are not followed, persons failing to do so will be subject to both criminal sanctions found outside of the Act - notably homicide offences - but also new and significant criminal offences, punishable in many instances by life imprisonment, created by the Act. Viewed in this way, criminal law provides the impetus to VAD processes: it renders

\footnotetext{
54 Ibid ss 83,84 .

55 Ibid $s 83$.

56 Ibid s 84 .

57 Ibid ss 79-82.
} 
the provisions, including VAD processes, active and is the mechanism through which VAD is therefore enacted. ${ }^{58}$ The criminal sanction regime found in the Act is that which gives authority and 'grip' to VAD processes, and in so doing is that which, legally speaking, produces VAD. It is in and through this sanctioning regime that the Act comes into being.

It is not only the presence of the criminal sanctioning regime, and its action as a 'tether' that gives effect to the Act, which renders visible how criminal law remains at the heart of VAD. So too does the way in which the criminal law is used to produce this new form of death - a 'voluntary assisted death' - itself, through its strategic withdrawal and deployment; a tactical use of criminal law to define and thus buttress the authority of VAD processes and this new form of death itself. I expand on this tactical use of criminal law here by reflecting on criminal law's deployment to define and give authority to VAD itself, as well as the VAD processes defined in the Act.

As to the definition of a voluntary assisted death 'itself', criminal law's deployment to establish this new form of death is best seen in a historical light. The form of death now described as a voluntary assisted death has historically constituted a serious criminal offence, namely, some form of homicide offence either directly or by way of accessorial liability. With the advent of the Act, one might expect or have hoped for an evacuation of the criminal law from the scene of a voluntary assisted death. And, in one sense, this has been achieved; the criminal law has been 'peeled back' from application to the scene of a voluntary assisted death. However, this withdrawal is a withdrawal from a tightly defined space, and it is the criminal law that is used to mark out and construct what a voluntary assisted death in fact 'is'; as that which takes place within the boundaries established by the (redescribed and much expanded) criminal law. In this sense, criminal law has been evacuated from the tightly defined space of 'voluntary assisted death', but it is this very evacuation that achieves the definition of a voluntary assisted death, in and through the movement of withdrawal and establishment of (even firmer) criminal legal boundaries around such deaths. In this sense, criminal law provides both the 'topographical features' and 'borders', which together produce voluntary

58 One reading of this might be that the Act is entirely an instrument of the criminal law and these 'administrative processes' are therefore a set of criminal offence elements, albeit rendered in an unusual level of detail. 
assisted deaths. Its re-inscription in the domain of death - with expanded reach and a larger number of offences - defines what a voluntary assisted death in fact 'is'. 59

In addition to the use of the criminal law's jurisdiction to produce voluntary assisted death 'itself', the criminal law is also mobilised in the VAD regime in order to establish the various processes used to govern and administer VAD. The governance of VAD relies on a mixture of procedures and pronouncements on various question of 'status' and the working through of detailed processes in order to navigate access to a voluntary assisted death. Like voluntary assisted death 'itself', these processes and statuses are fundamentally a product of the criminal law. In a manner similar to that of the criminal law's production of the new form of (voluntary assisted) death that the Act ushers in, the criminal law's sanctioning regime defines the specific processes and statuses used by VAD to gain access to such a death. It does so through the same practice of shaping the boundaries of those processes that lead to the newly decriminalised terrain of voluntary assisted death. Guarded on all sides by the criminal law and its offences, these processes are the only ones that may facilitate access to a voluntary assisted death, and their very nature and pathway are defined by the tactical arrangement of criminal law's jurisdiction by the Act.

To illustrate with a practical example: Why might it matter at all that whether or not a 'co-ordinating medical practitioner' will make an application for a self-administration permit 'in the prescribed form'?; 60 or that a person will return the voluntary assisted dying substance to a pharmacist at the dispensing pharmacy?; ${ }^{61}$ or will inform the person to whom the voluntary assisted dying substance is being dispensed that they are 'under no obligation to self-administer' the substance? ${ }^{62}$ It is because the Act provides that a registered health practitioner or other person will be criminally sanctioned (in both senses of the term) based on their acting in accordance with the processes as established by the Act. The 'stick' of the criminal law is that which provides an imprimatur and power to the otherwise 'free floating' processes described in the Act. It gives them shape and effect. Without the criminal law's buttressing of the boundaries

59 This could, of course, be achieved by an alternate legal ordering - through administrative or civil processes perhaps. However, in this instance, it is criminal law that performs this work.

60 Voluntary Assisted Dying Act (n 2) s 55.

61 Ibid.

62 Ibid s 58. 
of these processes, these processes would struggle, or be unable, to establish their authority. This is no mere 'stick', designed to ensure that a process is followed. Rather, the criminal law here shapes and establishes a very particular process, the violation of which will halt access to VAD and cause the sanctioning regime to punish - up to and including with life imprisonment - those who fail to follow the process in its fine detail.

The net increase in serious criminal offences and the widening of the jurisdiction of criminal law in this field of practice makes it clear that the Act is deeply invested in the use of the criminal law. The form of use of the criminal sanction as that which produces both voluntary assisted dying 'itself' and the complex of VAD processes and status questions only adds to the claim that the Act is itself deeply and fundamentally reliant upon the criminal sanction in order to produce and operate VAD, in Victoria at least. The 'legal mechanics' of these processes remain reliant upon the criminal sanctioning regime established by the Act, and the Act's operation, enforcement and authority emanates from its criminal sanction regime. The legal rationale for these various 'processes', including those that involve administrative decision-making or which might enliven rights to administrative review, remain traceable directly to the question of whether or not acts performed by persons will or will not enliven criminal sanction. ${ }^{63}$ I am not claiming that the act is only or purely an act of criminal law. It is not. It establishes and relies upon, for example, decisions and activities of the executive at times - however, these remain enclosed within the broader criminal sanction regime, where the successful completion or compliance with administrative processes establishes the proof of a criminal offence.

\section{The distribution of (voluntary assisted) death through the criminal sanction}

In this final section, I want to argue that criminal law, in the guise of the Act, distributes death according to the biopolitical model of Foucault. To do so I will attempt to elaborate how the criminal legal/ juridical sanction is the mechanism by which the criminal law performs a distribution of death, and thus its biopolitical role.

63 In other words, these 'processes' may be thought of, simply, as (some of) the elements of offences rendered in unusually detailed form. Given both the historical and now expanded criminalisation of particular forms of death, these processes that the Act describes are best understood - from a position of law - as detailed elaborations of when criminal sanction will or will not apply. 
According to the literature and debate surrounding VAD and similar regimes, these regimes offend against important principles of human dignity and care or, alternatively, provide a salutary system that is responsive to community demand for more adequate control over their end of life. Arguments in the former camp have tended to focus on the difficulties and dangers of VAD implementation and the significant risks to individuals, the meaning of healthcare and resourcing for endof-life care. Those arguments in the latter camp have seen the ongoing criminal sanctioning of forms of VAD-like activity as an embarrassment to an 'enlightened' liberal politics and an affront to patient/human autonomy, while generating accusations of a lack of mercy in the face of human suffering. ${ }^{64}$

What I want to propose here is a different perspective on VAD. ${ }^{65}$ One that is perhaps at a higher generality than these competing perspectives. This view is that VAD can be fruitfully understood as a biopolitical apparatus that differentially distributes death within a population by use of the criminal sanction. What this particular distribution should look like is a secondary question. Rather, what I want to do here is to show that a differential distribution is being put into effect by use of the criminal law. To do so, I will return briefly to Foucault and describe how his understanding of the biopolitics that is centred on the governance of life can come to kill.

For Foucault, biopower and biopolitics are focused upon the production and administration of life up to the limit of biopolitical authority, the limit of life: death. VAD regimes introduce a tension to theorisation of biopolitical governance. This is a tension between the death-orientation of VAD and the life-preserving orientation of the biopolitical state. Appearing as a form of conflict within the theorisation of biopolitics, an individual's wish 'to die' being facilitated by the state seems to conflict with the state's role according to biopolitical theory as that which has

64 I would add a third approach, that has not been advanced in the literature as yet - safety. Given the consistent inability of the health system to offer services that are safe, even simple services uncontrolled by strict regulation, I wonder if the health system will be able to offer VAD services in a 'safe' manner. If past performance is anything to go by, then VAD will be subject to workarounds and other quality and safety failures. Although, if VAD proves successful - in the sense of safe - then this might also be an argument for a re-regulation of other health system functions along the lines of $\mathrm{VAD}$ including criminal sanctioning for system stakeholders and practitioners.

65 Although I don't wish to say that this view is superior to the existing debate regarding the nature and impacts of VAD. 
a role to 'protect' and 'foster' life ${ }^{66}$ As Jennifer Hardes puts it, if we accept Foucault's claims that biopolitical governance aims to cultivate the life of a population, then cases where individuals actively desire death disrupt such a life-advancing biopolitical logic and should be opposed by the biopolitical state. ${ }^{67}$

Foucault asserts that a biopolitical regime of power 'allows' individuals within populations to die (that are 'let die') rather than having death inflicted upon them in the manner of sovereign power of old. However, with the construction and identification of a particular division or 'biosocial collectivity', ${ }^{68}$ as Rabinow and Rose term it, a 'break' ${ }^{69}$ opens up in the populace that allows the operation of biopower to make or let die in a particular way, ${ }^{70}$ addressed to a particular subpopulation. 'Race' was one such biosocial collectivity that Foucault reflected on. Racial groups, the racial 'hierarchy' and all of the attendant quasi-biological framing of the discourse of 'race' as a biosocial collectivity all function to create a break within the broader populace, a break that creates new opportunities for the differential application of biopower as between these newly formulated groupings that appear to be biologically based. Regardless of the particular subpopulation, this division into various subpopulations along allegedly biological lines is

a way of fragmenting the field of the biological that power controls ... It is a way of separating out the groups that exist within a population ... a way of establishing a biological type caesura within a population that appears to be a biological domain. ${ }^{71}$

66 See Hanafin on this question: Patrick Hanafin, 'Rights of Passage: Law and the Biopolitics of Dying' in Rosi Braidotti, Claire Colebrook and Patrick Hanafin (eds), Deleuze and Law: Forensic Futures (Palgrave Macmillan, 2009) 47; but see Hardes who engages with Derrida to read this conundrum in a criminal legal context: Jennifer J Hardes, 'Fear, Sovereignty, and the Right to Die' (2013) 3(1) Societies 66.

67 Hardes (n 66).

68 Rabinow and Rose (n 16) 197, 207.

69 Ibid 201 (such divisions allow power to 'subdivide a population into subspecies, to designate these in terms of in terms of a biological substrate, and initiate and sustain an array of dynamic relations in which the exclusion, incarceration or death of those who are inferior can be seen as something that will make life in general healthier and purer'). See and compare Golder's discussion of the same material: Golder (n 6) 101-3.

70 See the discussion of the differences between 'making' and 'letting' die, Rabinow and Rose (n 16), see for example 203, 211.

71 Foucault, Society Must Be Defended (n 27) 255. See also Golder's presentation of this line of thought at: Golder (n 6) 102. 
In short, it is a separation of those that are worthy of life and those that are not, of 'what must live, and what must die..$^{72}$

In the VAD regime, the criminal law - and those who cooperate with it - bring about a differential distribution of death through the criminal sanction, enacting either a form of lethal violence or merciful death, by way of the creation and use of the emergent biosocial collectivity of the dying'. Using this new biosocial category as its principle of division (the 'biological type caesura' of VAD), the state is able to classify and sort those who may and those who may not die by way of VAD, and in so doing identifying those that are worthy of life and those that are not, of 'what must live, and what must die'. ${ }^{73}$

The construction of this new group within the population is achieved primarily by the criminal sanction applying differentially to both persons who seek death and those who - as agents of the state and biomedicine may grant it. ${ }^{74}$ The biopolitical effect of this criminal sanctioning regime results in particular persons - 'the dying' - being exposed differentially to death. This new biopolitical category 'enlivens possibilities for regulation', allowing 'for greater calculated exposure to violence and death'. ${ }^{75}$ Thus, by allowing some and disallowing others, the VAD criminal sanction results in differential access to a voluntary assisted death and thus a differential distribution of death within the population as a whole. In the manner described above, the criminal legal apparatus is used to enact the state's biopolitical function of protecting and cultivating life until that life is no longer a life worth living and passes beyond the limit of biopower's domain.

The VAD regime does more than simply 'allow' or 'disallow' access to a voluntary assisted death, in the manner of an administrative process. Rather, it provides a differential exposure to such deaths by the tactical withdrawal (allowing) and application (disallowing) of the existing and now greatly expanded criminal offence regime. Using its newly constructed socio-biological collectivity of 'the dying' as the vector upon which the criminal law is either withdrawn or applied, two moves are made. On the

72 Foucault, Society Must Be Defended (n 27) 255.

73 Ibid.

74 As the work of Courtney Hempton and Catherine Mills shows, Hempton and Mills, 'Constitution of "the Dying"' (n 7).

75 Linda Steele, 'Disabling Forensic Mental Health Detention: The Carcerality of the Disabled Body' (2017) 19(3) Punishment \& Society 327, 331. 
one hand the criminal legal sanction of VAD 'carves out' and exempts those whose lives are no longer worth living/protecting/cultivating from the biopolitical protection of the state through its criminal prohibition and sanction against killing. At the same time, the criminal sanction of VAD sorts persons, admitting some persons and not others to access $\mathrm{VAD}$, authorising particular persons to kill with protection from criminal liability by the state for their instituting death.

In fashioning this tactical 'allowing' and 'disallowing' of the criminal law, the state sanctions either lethal violence or dignified death - depending on the perspective adopted - against 'the dying' by its structuring of the field by strategic (re)description of liability. While doing so, it also reinforces the status of this group as 'life not worth living' through its strengthening of the criminal law at the boundaries of this socio-biological collectivity - introducing new criminal laws for making and letting die those who do not belong to that subcategory of the population to be governed.

\section{Conclusion}

This chapter is a first attempt at testing whether the criminal law is simply a supplement to other more 'biopolitical' technologies of power or whether criminal law itself can function as a fundamental component of the biopolitical apparatus. I have argued above that the criminal law through the mechanism of the sanction that can both allow and disallow - operates to construct and make functional the biopolitics of VAD. In so doing, I have used Ben Golder's refocusing of biopolitics to highlight its work as a mechanism for the differential distribution of death, in which death/VAD is distributed along the division between 'the dying' and others. Those who belong to this socio-biological collectivity of 'the dying' are killed by the state's withdrawal and application of criminal law. If VAD achieves this differential distribution of death, abandoning particular collectivities to a greater exposure to death, then this is achieved through the medium of the criminal law sanction.

How (criminal) law itself advances biopolitics is a question that few have tackled, preferring to ignore 'black letter' law or to give it a treatment in such broad brush strokes that the legal materials are 'lost' or misinterpreted in the process. This is to say that bringing VAD, criminal law and biopolitical analysis together advances theory and method in the analytics of biopower. 
This analysis advance practice in two ways. First, all of the analysis and critique - both in support, questioning or critical of VAD - is really a wrestling with what shape we wish our biopolitics to be. Worries about the differential effects of VAD on marginalised communities or vulnerable persons, or claims of its salutary aspects for individual autonomy, are competing claims about a distribution of death and thus about the shape of our biopolitics. Understanding how the Act itself activates and achieves its biopolitical ends through the criminal law - whatever they may in fact be and whatever we may think of them - is to describe and explain how the act and VAD really 'works' biopolitically. Second, an attentiveness to formal legal materials and their operation creates the opportunity for analysis to contribute to reform. If, as Foucault boldly wrote, 'knowledge is not for knowing, knowledge is for cutting, ${ }^{76}$ closer attention to formal law and its effects is necessary. Without such a detailed attention we close off much of the potential for a Foucauldian analysis of law to have any purchase on law and legal practices informed by it.

\section{Bibliography}

\section{A Articles/books/reports}

Braidotti, R, 'Biomacht und nekro-Politik. Überlegungen zu einer Ethik der Nachhaltigkeit [Bio-Power and Necro-Politics. Reflections on an Ethic of Sustainability]' (2007) 13(2) Springerin: Hefte fur Gegenwartskunst 18

Braidotti, Rosi, 'The Politics of "Life Itself" and New Ways of Dying' in Diana Coole and Samantha Frost (eds), New Materialisms: Ontology, Agency, and Politics (Duke University Press, 2010) doi.org/10.1215/9780822392996-009

Carter, David J, 'HIV Transmission, Public Health Detention and the Recalcitrant Subject of Discipline: Kuoth, Lam $v$ R and the Co-Constitution of Public Health and Criminal Law' (2016) 25(2) Griffith Law Review 172 doi.org/10.1080/10383441.2016.1238563

Carter, David J, 'Transmission of HIV and the Criminal Law: Examining the Impact of Pre-Exposure Prophylaxis and Treatment-as-Prevention' (2020) 43(3) Melbourne University Law Review 937

76 Michel Foucault, 'Nietzsche, Genealogy and History' in Paul Rabinow (ed), The Foucault Reader (Pantheon Books, 1984) 88. 
Carter, David J, 'The Use of Coercive Public Health and Human Biosecurity Law in Australia: An Empirical Analysis' (2020) 43 University of New South Wales Law Journal 117

Faunce, Thomas, 'Justins v The Queen: Assisted Suicide, Juries and the Discretion to Prosecute' (2011) 18 Journal of Law and Medicine 706

Foucault, Michel, The History of Sexuality. Volume 1: The Will to Knowledge, tr Robert Hurley (Penguin, 1998)

Foucault, Michel, 'Nietzsche, Genealogy and History' in Paul Rabinow (ed), The Foucault Reader (Pantheon Books, 1984) 76

Foucault, Michel, 'Society Must Be Defended': Lectures at the Collège de France, 1975-1976 (Picador, Reprint ed, 2003)

Golder, Ben, 'The Distribution of Death: Notes towards a Bio-Political Theory of Criminal Law' in Matthew Stone, Illan rua Wall and Costas Douzinas (eds), New Critical Legal Thinking: Law and the Political (Taylor \& Francis, 2012) 91

Golder, Ben and Peter Fitzpatrick, Foucault's Law (Routledge-Cavendish, 2009)

Hanafin, Patrick, 'Rights of Passage: Law and the Biopolitics of Dying' in Rosi Braidotti, ClaireColebrookandPatrickHanafin(eds), DeleuzeandLaw:Forensic Futures (Palgrave Macmillan, 2009) 47 doi.org/10.1057/9780230244771_4

Hardes, Jennifer J, 'Fear, Sovereignty, and the Right to Die' (2013) 3(1) Societies 66 doi.org/10.3390/soc3010066

Hempton, Courtney and Catherine Mills, 'Constitution of "the Already Dying": The Emergence of Voluntary Assisted Dying in Victoria' (2021) 18(2) Journal of Bioethical Inquiry 265 doi.org/10.1007/s11673-021-10107-1

Hempton, Courtney and Catherine Mills, 'Constitution of "the Dying": Voluntary Assisted Dying Law Reform in the Australian State of Victoria' (Conference Paper, Australasian Association of Bioethics and Health Law, 2 July 2018)

Kubiak, Anna E, 'Assisted Dying in the Context of Biopower' (2015) 21(1) Anthropological Notebooks 23

Kubiak, Anna E, 'The Discourse of Biopower against Disturbances of the Boundary between Life and Death' (2011) 15(Special) Annales Universitatis Apulensis Series Historica 481 
McDorman, Todd F, 'Controlling Death: Bio-Power and the Right-to-Die Controversy' (2005) 2(3) Communication and Critical/Cultural Studies 257 doi.org/10.1080/14791420500198571

Neilson, Brett, 'Anti-Ageing Cultures, Biopolitics and Globalisation' (2006) 12(2) Cultural Studies Review 149 doi.org/10.5130/csr.v12i2.2341

Özpolat, Gürhan, 'Between Foucault and Agamben: An Overview of the Problem of Euthanasia in the context of Biopolitics' (2017) 7(2) Beytulhikme An International Journal of Philosophy 15 doi.org/10.18491/beytulhikme.373466

Rabinow, Paul and Nikolas Rose, 'Biopower Today' (2006) 1(2) BioSocieties 195 doi.org/10.1017/S1745855206040014

Steele, Linda, 'Disabling Forensic Mental Health Detention: The Carcerality of the Disabled Body' (2017) 19(3) Punishment \& Society 327 doi.org/10.1177/ 1462474516680204

Veitch, Kenneth, 'Medical Law and the Power of Life and Death' (2006) 2(2) International Journal of Law in Context 137

\section{B Legislation}

Voluntary Assisted Dying Act 2017 (Vic)

Voluntary Assisted Dying Act 2019 (WA)

\section{Other}

Silva, Kristian, 'Voluntary Euthanasia Patients Caught in Red-Tape Bottleneck', $A B C$ News (online, 18 July 2019) <https://www.abc.net.au/news/2019-07-18/ voluntary-euthanasia-patients-caught-in-red-tape-bottleneck/11320626>

Victoria, Parliamentary Debates, Legislative Council, 21 September 2017, 2949 (Jill Hennessy, Minister for Health) 
This text is taken from Voluntary Assisted Dying: Law? Health? Justice?, edited by Daniel J Fleming and David J Carter, published 2022 by ANU Press, The Australian National University, Canberra, Australia.

doi.org/10.22459/VAD.2022.09 